\title{
〈総説論文：Review article〉
}

\section{リハビリした油污染海鳥の放鳥後の生残の検証}

\author{
岡 奈理子*
}

\section{Evaluation of Post-release Survival of Rehabilitated Oiled Seabirds}

\author{
Nariko Oka*
}

\begin{abstract}
Oil spills have often impacted large numbers of neritic and coastal seabirds, especially during the second half of the 20th century. In the Japan Sea, a large heavy-oil spill from the Russian tanker 'Nakhodka' in January 1997 oiled many seabirds. A total of 1,315 dead and emaciated birds was counted on beaches, and among them, about 90 birds were released after cleaning and rehabilitation. Oiled bird rehabilitation has a long history in some countries, and the total number of birds that has been rehabititated and released throughout the world is at least in the low tens of thousands. From a conservation biological perspective, the need for an evaluation of the population-level contribution of released birds has been recognized since the 1980's. Very recent studies using recoveries of ringed diving birds (Uria aalge, Aechmophorus occidentalis/A. clarkii, Melanitta fusca, Melanitta perspicillata) in sub-high-latitude ocean regions indicate that post-release survival of rehabilitated birds is extremely poor (e.g., the survival rate of English Uria aalge in the first year after release was $0.6 \%$, and the life expectancy of North American Uria aalge was 9.6 days). A radiotelemetry study of pelicans (Pelecanus occidentalis), which are marine surface feeders along coastal areas in middle latitudes, indicates that rehabilitated pelicans do not appear to breed, though survival is slightly longer than for diving birds. In contrast, studies on marked penguins (Spheniscus demersus) in middlelatitude waters off South Africa have shown that about half of rehabilitated penguins survived in the critical first year after release, and afterwards had a survival rate nearly as high as non-oiled penguins. For this species, listed as "near-threatened" in the IUCN Red Data Book, rehabititation has probably slowed to some extent the decrease of local populations or, in some cases, perhaps slowed the decrease of the population of this species as a whole. If rehabilitaion techniques can be improved for other diving birds (the most vulnerable to oil spills in northern neritic and coastal waters) and for surface feeders so that post-release survival is increased, oiled bird rehabilitation could become a valua-
\end{abstract}

Received 8 December 1998, Revised 9 January 1999, Accepted 12 January 1999.

* (財)山階鳥類研究所研究部, =270-1145 千葉県我孫子市高野山115 E-mail: DZD00212@nifty.ne.jp

* Research Division, Yamashina Institute for Ornithology, Konoyama 115, Chiba, 270-1145 Japan. E-mail: DZD00212@nifty.ne.jp 
ble tool for the conservation of endangered or seriously threatened species when impacted by oil spills.

Key words: Oil spill, Oiled seabird, Evaluation of post-release survival, Ringed birds, Redio-telemetry, Uria aalge, Spheniscus demersus, Pelecanus occidentalis.

キーワード：油の流出, 油污染海鳥, 放鳥後の生残評価, 標識鳥, 電波発信機, ウミガラス, ジャッカスペンギン，カッショクペリカン.

\section{はじめに}

20 世紀は 10 年刻みに石油の生産・消費量が倍増した世紀であった。海上の油污染で海洋生 物全般への影響が広範囲にわたり憂慮されるなかで (Nelson-Smith 1970, 1972), 海洋生物の油 污染の悲惨さが人の目に最も触れる海鳥に対し, 幾つもの国々で救済活動が継続的に行われて きた（Frost ら 1976, Clark 1978, Adams 1994, 他)。一部の国々や地域では油污染海鳥の発見か ら放鳥までのリハビリプログラムも準備されている（Maki 1990，マゼット 1998）。日本でも 1997 年 1 月に日本海でロシア船から多量の重油が流出し, 海鳥が油污染の被害を受け, 環境庁 の調べでは海岸で発見されたものだけでも 1,315 羽が死亡あるいは衰弱し，救護された鳥の約 90 羽が洗浄, リハビリ後に放鳥されている。

リハビリ後放鳥された個体が野生復帰し, 繁殖に参加し, 野生個体群に関与できるようにな ることが，油污染した海鳥の救済の最終目標と位置づけるならば，油污染鳥の救護努力が現実 によ゙こまで実を結んでいるのかが長く疑問視されてきた (Clark 1978, Vauk 1984)。さらに, 救 護した油污染鳥を良好な条件下でリハビリして放鳥するには高いコストがかかるため，今世紀 に激増し，繁殖地の占有や雛や親鳥の捕食などで小型海鳥の個体数を減少させた大型力モメ類 や，十分に個体数の多い海鳥種まで包括的に救護しリハビリすることに対して，保全生物学的 視点からの問いかけがされてきた (Clark 1978, Vauk 1984)。前者のリハビリによる油污染鳥の 救済の効果に関して，1990 年代に入り検証主義の立場から実績の点検が始まり，1990 年代半ば からは油污染鳥の放鳥後の生残についての分析結果が相次いで提出されてきた（Adams 1994, Sharp 1996, Camphuysen ら 1997, Underhill ら 1997, Wernham ら 1997)。油污染海鳥の救護の動 機が自然発露的, 人道主義的立場から出発しており, 被災鳥の選別救護は現場で関わる人へ心 理的ストレスを与える懸念むあって, 後者の, あらゆる被災鳥を救護することへの保全生物学 的な視点からの問いかけについては，いまだ科学的議論に発展していない。最近では影響力の 大きい学術誌で, 油污染鳥のリハビリは手間と経費の割に得られる効果が少ないとする否定的 な見解が提出されている (Mead 1997, Estes 1998)。そうしたなかで 1998 年夏の第 22 回国際鳥 学者会議のワークショップでは, 油污染鳥の救護効果の有無を問い直し, リハビリ技術の向上 の必要性と問題点が論議された (Wernham \& Williams 1998)。

本稿では, これまでに提出された個々の論文内容を整理し, 油污染しリハビリ放鳥された海 鳥の生残の現況を論ずる。 


\section{油污染鳥のリハビリ放鳥効果について}

これまでに行われた油污染鳥の洗浄・リハビリ放鳥後の生残の検証方法は，次の二つに大別 される。1) 油污染リハビリ鳥と通常の野生個体群の, 放鳥から回収までの時間と距離, 回収率 の比較（Sharp 1996, Wernham ら 1997, Camphuysen ら 1997）と，電波発信機による追跡可能時 間と行動圏の比較（Anderson ら 1996）と，2) リハビリ鳥の集団繁殖地での目視（Randall ら 1980, Adams 1994, Underhill ら 1997) である (Table 1)。どちら屯識別の可能な個体の集積デー 夕に基づく。1) のSharp (1996) では，リハビリ中の個体の幾つかのパラメータと，回収までの 時間, 生残との相関も分析した。対象種は, 油污染の被害が多い潜水性鳥類のうち, ウミガラ ス類 1 種（Sharp 1996, Wernham ら 1997, Camphuysen ら 1997), カイッブリ類 1 種 (Sharp 1996), 海鴨類 2 種 (Sharp 1996) と, 非潜水性鳥類のペリカン類 1 種（Anderson ら 1996）であ る。2) の繁殖地での目視はペンギン類 1 種（Randall ら 1980, Adams 1994, Underhill ら 1997） である。その結果, 油污染鳥の救済効果は, 前者が抢抢むね極めて否定的, 後者のペンギンで 極めて肯定的な結果となり，明暗を分けた。リハビリ鳥の生息海域は，救済効果に否定的な見 解が北半球の中〜亜高緯度海域で, 肯定的な見解が南半球の中緯度海域で出されている。どち らも寒流と暖流の潮境海域か, 亜高緯度であっても, 暖流の流入する海域にあたる。油污染鳥 の救護の歴史は，ともに長い。次にそれぞれの内容を種ごとに詳論する。

\section{1-1. 潜水性鳥類の場合}

\section{1. 油污染鳥の救済効果否定側}

\section{A) ウミガラス}

北太平洋中緯度〜巠高緯度で最も多く油污染するウミガラス (Uria aalge, 英名 Guillemot, アメリカ合衆国・カナダ通称名 Common Murre）（基垔種の 1 アラスカ個体群の年平均体重 $980 \mathrm{~g}$ (Gaston \& Jones 1998)）の, 油へ被曝後, 保護飼育施設に収容され標識を付けて放鳥され た個体数は，1985 年以後の英国だけでも 2,912 羽 (Wernham ら 1997)，1979〜1995 年のオラン ダで 1,723 羽 (Camphuysen ら 1997), 1969 1994 年の北米で 1,272 羽 (Sharp 1996) となり，こ れらを総計すると 5,907 羽にのぼる。このうち死亡回収されたのは 263 羽（回収率 4.4\%）で, 英国で 1985 年以前に放鳥され回収された 64 羽を合わせた計 327 羽が油污染経験鳥の分析対象 個体である。北米ではアメリカ合衆国漁業野生生物局の鳥類標識センターで管理されている標 識鳥のデータのうち, 回収時に白骨化していたり, リングだけの回収例や, 繁殖地で再目視し たといった個体は除去されている。

油污染鳥を評価するために用いられたウミガラスの健常鳥 (非油污染鳥) は, 英国と北米で は繁殖地で主に㮲を標識放鳥したグループからなる。英国では繁殖地で 1985 年以後 11,844 羽 が放鳥され，1,897 羽が死亡回収（回収率 16\%) されている。このうち 1,784 羽は雛時に標識し たもので，標識時に既に発育を終えていた個体は 113 羽であった。北米の分析鳥も，ほとんど が㮲に標識したもので，カナダ・ニューファンドランド州の 23,475 羽，アメリカ・オレゴン州 の 2,716 羽, カリフォルニア州の 574 羽の計 26,765 羽のうち, 死亡回収された 641 羽（回収率 2.4\%）のウミガラスである。オランダが比較したのは, 英国ウェールズのメイ島で標識放鳥さ れた 2,176 羽（放鳥時に既に発育が完了していた鳥であり， $22 \%$ が若鳥/亜成鳥，残りの $78 \%$ 
岡 奈理子

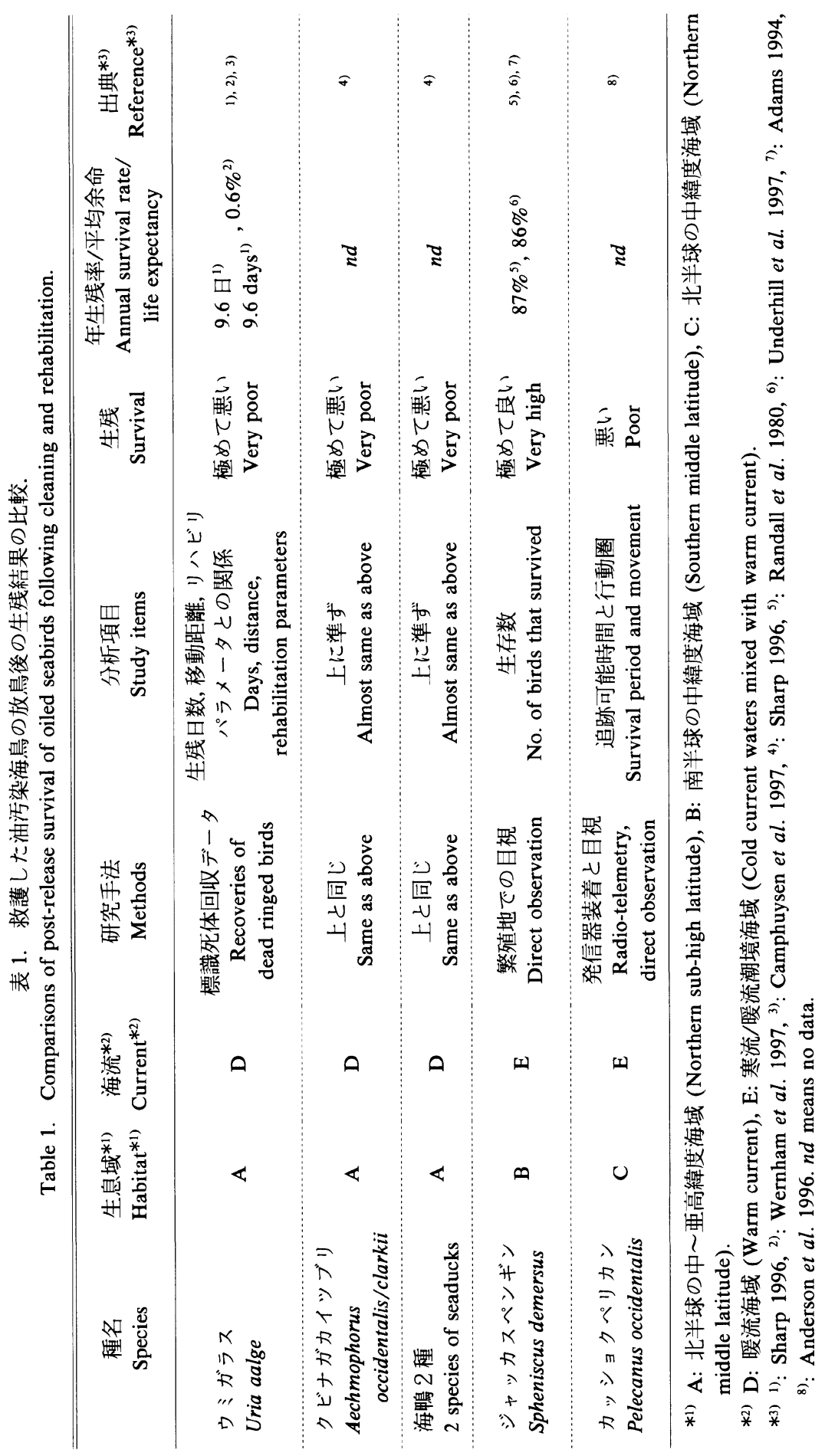


表 2. 北米と英国，オランダで標識放鳥された油污染鳥と非油污染鳥の放鳥から回収までの日数の比 較; (A) ウミガラス, (B) 北米の他の海鳥種.

Table 2. Mean and median days survived for oiled and non-oiled seabirds after release in North America, Britain and the Netherlands based on ringing recoveries: (A) Uria aalge and (B) other North American seabird species.

(A) ウミガラス Uria aalge

\begin{tabular}{|c|c|c|c|c|c|}
\hline & $\begin{array}{c}\text { サンプル数 } \\
\mathrm{n}\end{array}$ & $\begin{array}{l}\text { 平均值 } \\
\text { Mean }\end{array}$ & $\begin{array}{l}\text { 中央值 } \\
\text { Median }\end{array}$ & $\begin{array}{l}\text { レンジ } \\
\text { Range }\end{array}$ & $\begin{array}{l}\text { 引用文献* } \\
\text { Reference* }\end{array}$ \\
\hline \multicolumn{6}{|l|}{$\begin{array}{l}\text { 油污染鳥 Oiled } \\
\text { 北米 North America }\end{array}$} \\
\hline 全調查年 All years & 78 & 39 & 6 & $0-919$ & 1 \\
\hline 1990 年以前 before 1990 & 68 & 29 & 6 & $0-919$ & 1 \\
\hline 1990 年と以後 1990 and later & 10 & 107 & 8 & $0-810$ & 1 \\
\hline 英国 England & & & & & \\
\hline 1985 年以前 before 1985 & 64 & 104 & 7 & $0-3130$ & 2 \\
\hline 1985 年と以後 1985 and later & 77 & 29 & 7 & $1-381$ & 2 \\
\hline オランダ Netherlands & 108 & 164 & 12 & $0-2973$ & 3 \\
\hline $\begin{array}{c}\text { 非油污染鳥 Non-oiled } \\
\text { 北米 North America }\end{array}$ & & & & & \\
\hline $\begin{array}{l}\text { 主に雊 Mostly nestling } \\
\text { 英国 England (1985 and later) }\end{array}$ & 641 & 485 & 216 & $1-9259$ & 1 \\
\hline 敏隹 Nestling & 1784 & 406 & 227 & $10-3762$ & 2 \\
\hline $\begin{array}{l}\text { 成熟鳥 Fully-grown } \\
\text { オランダ Netherlands }\end{array}$ & 113 & 876 & 599 & $3-3795$ & 2 \\
\hline 成熟鳥 Fully-grown & 57 & 1376 & 671 & $14-6118$ & 3 \\
\hline
\end{tabular}

(B) 北米のその他の海鳥種 Other North American seabird species

\begin{tabular}{|c|c|c|c|c|c|}
\hline $\begin{array}{c}\text { 種名 } \\
\text { Species }\end{array}$ & $\begin{array}{c}\text { サンプル数 } \\
\mathrm{n}\end{array}$ & $\begin{array}{l}\text { 平均值 } \\
\text { Mean }\end{array}$ & $\begin{array}{l}\text { 中央値 } \\
\text { Median }\end{array}$ & $\begin{array}{l}\text { レンジ } \\
\text { Range }\end{array}$ & $\begin{array}{l}\text { 引用文献* } \\
\text { Reference* }\end{array}$ \\
\hline 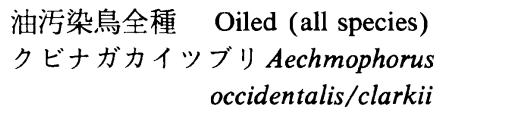 & 118 & 51 & 6 & $0-919$ & 1 \\
\hline 油污染鳥Ｏiled & 10 & 111 & 11 & $1-763$ & 1 \\
\hline 非油污染鳥 Non-oiled & 37 & 763 & 624 & $19-658$ & 1 \\
\hline $\begin{array}{c}\text { ビロードキンクロ Melanitta fusca } \\
\text { 油污染鳥 Oiled }\end{array}$ & 10 & 8 & 7 & $1-16$ & 1 \\
\hline 非油污染鳥 Non-oiled & 22 & 1019 & 466 & $8-4939$ & 1 \\
\hline $\begin{array}{l}\text { アラナミキンクロ Melanitta perspicillata } \\
\text { 油污染鳥 Oiled }\end{array}$ & 8 & 39 & 5 & $2-255$ & 1 \\
\hline
\end{tabular}

*: Sharp (1996), 2: Wernham et al. (1997), 3: Camphuysen et al. (1997).

が成鳥）のうち，死亡回収された 57 羽（回収率 2.6\%）についてである。

これら 3 ヶ国で油污染鳥と非油污染鳥の標識放鳥後の生残がそれぞれ比較分析された結果, 油污染経験ウミガラスの回収までの日数は平均で英国 29 日, 北米 39 日，オランダ 164 日と大 きくばらついたが，長期間生残した例外的な個体の影響を受けにくい中央值での比較では，北 米之英国で 6 日，7 日，オランダでも 12 日となり，いずれの国あるいは場所でリハビリ放鳥さ 
(A)ウミガラス Uria aalge

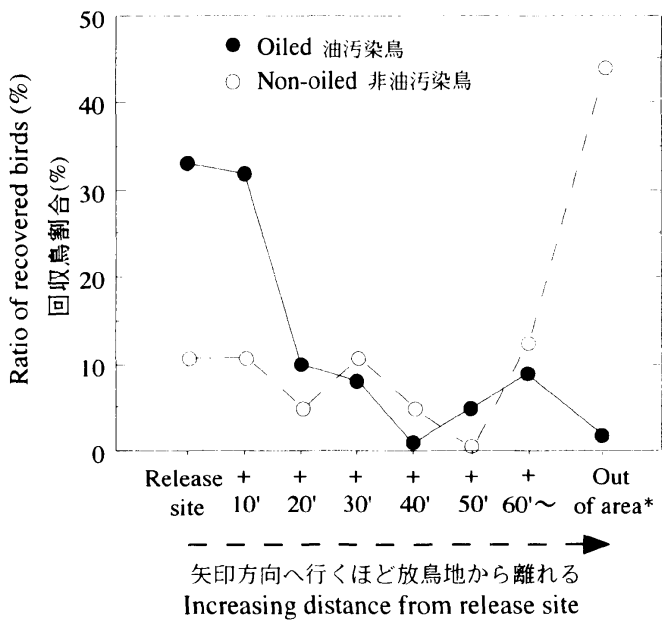

(B)力ッショクペリカン Pelecanus occidentalis

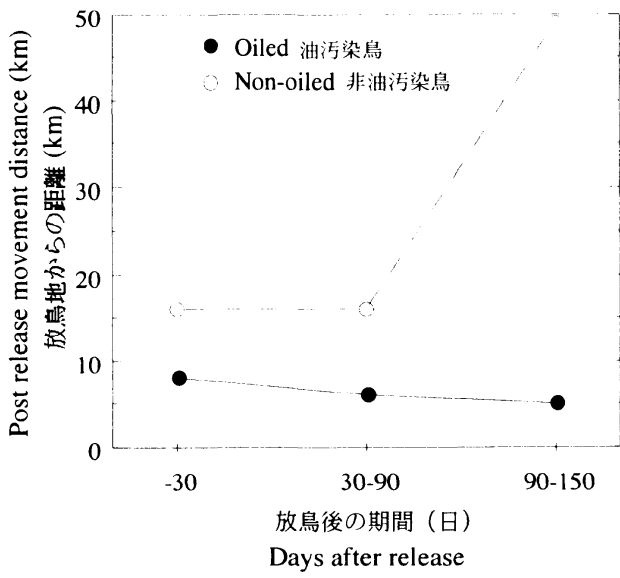

図 1. 放鳥した北米の (A) ウミガラスと (B) カッショクペリカンの, 油污染鳥と非油污染鳥の移動 の比較. (A) 放鳥地から緯度経度 10 分毎に離れた場所での回収鳥割合. *は放鳥した州あるい は郡外での回収.Sharp (1996) から作図. (B) 電波発信機による追跡調查で, 放鳥後 150 日ま での放鳥地からの距離を各期間ごとに中央值で図示する. Anderson ら (1996) から作図.

Fig. 1. Post-release movement of oiled and non-oiled (A) Guillemots Uria aalge and (B) Brown Pelicans Pelecanus occidentalis in North America in relation to release site. (A) Ratio of recovered birds by 10 -minute block of latitude and longitude from the release site. * shows the area outside of the borders of the state or province in which birds were released. Made from Sharp (1996). (B) Median distance from release site as determend by radio-telemetry. Made from Anderson et al. (1996)

れたウミガラスも放鳥後の生残日数は共に短かった (Table 2A)。北米では $94 \%$ が 60 日以内に 回収され，5ヶ月以上を経たのは全 78 羽のうち 5 羽，さらに 1 年以上を経たのは，そのうちの わずか 2 羽に過ぎず，放鳥された油污染りハビリ鳥の平均余命は 9.6 日と計算されている。

一方, 非油污染ウミガラスの放鳥から回収までの日数は, 放鳥時に既に発育を完了していた 成熟鳥群の中央值で 600 日前後 (英国で 599 日, オランダで 671 日), 初期死亡率が高い雛群の 中央值で約 220 日（北米で 216 日, 英国で 227 日）である。回収までの平均日数む, 北米の主 に雛放鳥群で 485 日, 英国の雛放鳥群で 406 日, 成熟鳥放鳥群で平均 876 日, オランダの成熟 鳥放鳥群で 1,376 日となり, 油污染経験鳥に比べて著しく長い。

北米の油污染ウミガラスの放鳥後の生残日数の平均值は, 1990 年以前では 29 日であったが, エクソンバルディーズ号の原油流出事故で油污染鳥の救護を本格的に体験した後の 1990 年以 後では 107 日と著しく伸びている。しかし，1990 年以後の回収数がわずかに 10 羽と少ないこ とああり，その差は有意ではない。また中央值は依然として僅かに 2 日伸びたに過ぎない。こ れとは別にいったん放鳥したものの保護飼育施設などに再収容された油污染リハビリ個体 82 羽では, 回収までの日数が平均でも 4 日と, さらに短い。回収場所む, 非油污染鳥では約 $45 \%$ の鳥が放鳥地から隔たった州外の水域で回収されたが，油污染鳥では $80 \%$ が放鳥地と同一水 域かその周辺で回収されている (Sharp 1996) (Fig. 1A)。 
英国でも油污染鳥の放鳥地と回収地の距離は中央值で 1985 年以前では $22 \mathrm{~km}(\mathrm{n}=64), 1985$ 年以後では悪化し $8 \mathrm{~km}(\mathrm{n}=77)$ となったが, 非油污染鳥では雊で標識放鳥された 1,784 羽で中 央値が $638 \mathrm{~km}$ であった。放鳥後最初の 2 ヶ月の月ごとの生残率は英国の油污染ウミガラスの 場合, 平均で $17 \%$ 之低く, この 2 ヶ月間にほとんどが死亡するが, 以後は放鳥 1 年目までの月 ごとの牛残率は平均 $86 \%$ に急上昇する。このように放鳥直後の死亡率が著しく高い結果, 油污 染鳥では放鳥初年の年生残率が $0.6 \%$ と計算されている。この海域の野生個体群の年齢別の平 均年生残率は満 1 歳までが $46 \%, 1$ 歳〜2 歳未満で 75\%, 満 2 歳〜3 歳未満で $88 \%$ と算出され ており（Wernham ら 1997）, 油污染を経験し放鳥された鳥の年生残率は健常鳥に比較して極め て低い。

オランダでは, 油污染鳥は放鳥後 1 ヶ月以内に約 $70 \%$ が回収され，1 年以内に全体の $92 \%$ が回収されたが，1 年以上経て回収された個体も $8 \%$ おり, 英国, 北米で放鳥された油污染鳥 より, 比較的生残率が高い。半年以上生残したウミガラス 16 羽の放鳥地と回収地の距離は平均 $404 \mathrm{~km}$ と伸びており, 回収されるまでの最長例では 8 年 1 ヶ月の記録がある (Camphuysen ら 1997)。イギリスでも最長例は，1985 年以前に放鳥された個体に， 8 年 6 ヶ月の記録がある。 Clark (1978) によると，1972～74 年の 3 年間にイギリスで放鳥された油污染リハビリウミガラ ス 88 羽のうち，7 羽が放鳥後 1 2 週間で死んで回収され，1 羽が衰弱して発見されているが, 1 羽が $800 \mathrm{~km}$ 離れたフランス北西部で回収され，2 羽が 4 ヶ月後に生きていたのが発見され，1 羽と, 同様に救護後放鳥されたミッユビカモメ Rissa tridactyla 1 羽が近くの集団繁殖地にいた のが確認されている。また Harris \& Wanless (1997) は, 繁殖期にウエールズのメイ島に戻った 1,000 羽を越える標識付きウミガラスの中に, 3 羽の油污染経験鳥 (2 羽がオランダ, 1 羽がドイ ッで放鳥）が混じっていたのを記載している。

以上みたように, ウミガラスの標識鳥の集積データに基づく 3 ヶ国での分析結果は, 油污染 鳥の放鳥から回収までの日数が中央值で北米, 英国でともに 6 日, 最も長いオランダでむ 12 日 にすぎず，放鳥初年の生残率は僅か $0.6 \%$ とする結果が英国で, 放鳥後の平均余命は 9.6 日之 する結果が北米で出されている。放鳥地から回収地までの距離もこの結果に同調し, 油污染ウ

ミガラスでは英国では半数が 10〜 $20 \mathrm{~km}$ 以内で回収され, 北米でも $80 \%$ が放鳥地付近かその 周辺で回収されており, オランダはわずかに良い傾向にあったあのの, 健常ウミガラスに比べ て放鳥後の生残は一様に著しく悪い結果が示されている。

\section{B) カイッブリ類と海鴨類}

北米で油污染しリハビリ後に標識放鳥されたウミガラスを除く海鳥は, 1969 年〜1994 年の 25 年間に 12 種計約 1,900 羽である。放鳥後, 死亡回収された計 127 羽のうち, 比較検定に耐え うる回収数のある, 先に論評したウミガラスと, クビナガカイッブリ (Aechmophorus occidentalis, Western Grebe)/(A. clarkii, Clark's Grebe) $(0.6 \sim 1.2 \mathrm{~kg}$ )（最近別種とされる), ビロードキン クロ(Melanitta fusca, White-winged Scoter, 北米通称 Velvet Scoter)（体重 $1.2 \sim 1.8 \mathrm{~kg}$ ), アラナ ミキンクロ (Melanitta perspicillata, Surf Scorter)（体重 $0.9 \sim 1.0 \mathrm{~kg}$ )の 4 種の計 118 羽が, 非污 染グループとの比較分析に供された (Sharp 1996)。その結果, 油污染鳥 118 羽の放鳥後の生残 日数は, 平均值が 51 日, 中央值が 6 日であった (Table 2B)。種別の中央值はクビナガカイッブ リの油污染鳥で 11 日なのに対し非污染鳥では 624 日, ビロードキンクロの油污染鳥で 7 日な のに対し非污染鳥で 466 日, アラナミキンクロの油污染鳥で 5 日となり, ウミガラスと同じ傾 
向にある。海鴨類の多くは狩猟対象にされる。油污染標識放鳥した 395 羽のビロードキンクロ のうち計算上 16 羽が銃猟で捕殺されると予測されるが，1 羽も報告がない。これらの結果はウ ミガラス同様, クビナガカイッブリ，ビロードキンクロ，アラナミキンクロの 3 種でむ野生復 帰がほとんどできなかったことを示唆している。

油污染リハビリ中に放鳥時期などを図る現行の指標のうち，9 パラメータ（收容時 PCV（血 中の細胞成分容積率), 放鳥時 PCV, 油の付着の程度, 白血球数, 全蛋白量, 洗浄日数, 飼育日 数, 収容時体重, 放鳥時体重）と放鳥後の生残日数の関係を, この潜水性鳥類 4 種一括で調べ たところ，ほとんどのパラメータが，放鳥後の生残日数の長短と無関係とする結果が得られて いる (Sharp 1996)。生残日数とわずかに相関が認められるのは, 飼育日数と油の付着の程度と, 放鳥時 PCV の 3 つであり, 前者が正, 後者が負の相関である。が，その相関の程度は最む高い 飼育日数であ $r^{2}$ が僅かに $14 \%$ に過ぎない。ウミガラスだけで有意な相関があったのは飼育日 数だけであるが, 飼育日数と生残日数にはこの解析中, 最も高い正の相関 $\left(r^{2}=32 \%\right)$ が認めら れている (Sharp 1996)。

\section{1-2. 表層索餌型鳥類の場合}

非潜水索餉型鳥類では, カッショクペリカン (Pelecanus occidentalis, Brown Pelican) を用いて 油污染放鳥後の生残が追跡調査されている（Anderson ら 1996）。カッショクペリカンは体重約 $3.5 \mathrm{~kg}$ で, アメリカ大陸の沿岸の主に低〜中緯度にかけて生息し, 海面に着水して索餌, あるい は低空から海面に突撃して採食し，海浜あるいは海上の構造物で過ごす習性が知られている (del Hoyo 1992)。Anderson ら (1996) は，北米西海岸で電波発信機と標識を付けて油污染り八 ビリ群と非污染群（通常の野生個体群）計 131 羽の行動を最長 2 年にわたり追跡している。油 污染群は 1990 年 2 月初旬と 1991 年 4 月初旬にカリフォルニアの Southern California Bight 海 域に流出した油で污染したカッショクペリカンのうち，それぞれ 2 3 週間のリハビリ後に放 鳥した 112 羽（幼鳥 19 羽を含む）で, 非污染群は 1990 年 3〜4 月に同海域で油污染被害を受け なかった地域個体群から捕獲した 19 羽（幼鳥 2 羽を含む）である。すべての個体に金属標識 と, 目視発見率を高めるために半数以上の鳥に色標識を付け, そのうちの油污染群 31 羽, 非污 染群 11 羽の計 42 羽の成鳥には発信器を装着した。油污染鳥のリハビリ後の放鳥には特に注意 を払い，南に位置し寒波の影響が少ない主要な夜埘の一つで，繁殖前に集団で滞在する場所を 選んだ。カリフォルニア海域と西バハ・カリフォルニア海域（北緯 23 度〜30度）を1990〜 1992 年に陸と空から受信機と目視で広範囲に探索した結果, 油污染鳥は非污染鳥より早期に受 信が途絶え，目視率も下がったが，その程度は先述した潜水性鳥類に比べて良好と言える。発 信機を装着した非污染鳥では半年目に 1 羽が行方不明になり，半年間の推定生残率は $91 \%$ で あったが，油污染鳥では行方不明が最初の 60 日間と 120〜180 日間で多発したものの，半年間 の推定生残率は初年度の 1990 年放鳥群で $33 \%$, 次年度放鳥群で $40 \%$ の, 平均 $36 \%$ である。油 污染鳥は, 23 羽中 12 羽の成鳥が放鳥前の 1 2 週間, コートシップディスプレーや, 他の雌,

雄，番いに固執したり，防御行動など繁殖に関係する行動を示したにもかかわらず，放鳥後す ぐにこうした行動をしなくなり，1 羽を除き，1990，1991，1992 年の繁殖期に，よ゙の繁殖地へ も飛来が確認されなかった。この 1 羽は 1990 年 4 月に数日間，島の繁殖地の一つを時にした が，すぐに大陸側の海岸に戻り 4 週間滞在後，発信が途絶えている。これに対して，非污染鳥 
は発信器を装着した 11 羽のうち 5 羽が 4, 5 月に繁殖地に飛来したのが追跡された。非污染鳥 は翌 1991 年も繁殖地で定位され，1992 年に少なくとも 3 羽が繁殖地で目視されている。繁殖 終了後は定常の北方への移動分散を始めている。放鳥後半年間の放鳥地からの移動距離は非污 染鳥では平均でも $100 \mathrm{~km}$ を越えたが, 油污染鳥では平均 $10 \sim 20 \mathrm{~km}$ 程度に過ぎない。さらに 中央值ではわずかに 5 8 km で, 非污染鳥の 16 49 km と比較し, 放鳥地に滞留する傾向が顕 著である (Fig. 1B)。油污染ペリカンが放鳥水域に滞在する傾向は, 北米と欧州の油污染ウミガ ラス之酷似する。潜水性鳥類と比較して, カッショクペリカンの放鳥半年の生残率 $36 \%$ ははる かに高いが，生残個体が繁殖群に加わった可能性は低い。

このように, 北半球中〜亜高緯度海域での油污染リハビリ海鳥の放鳥後の生残は, 潜水性鳥 類 4 種で著しく悪く, 非潜水性鳥類 1 種で悪く, 繁殖した可能性がないか, あってあ極めて少 数である。これまでのところ油污染を経験し救護され放された鳥の, それぞれの種, あるいは 個体群の保全への貢献は極めて低いとみられる。

これと極めて対照的なのが，次にみる南アフリカ共和国で油污染し，救護され放された ジャッカスペンギンである。

\section{2. 油污染鳥の救済効果肯定側}

\section{2-1. ペンギン類}

北半球のウミガラス類と類似ニッチを持つ南半球のペンギン類のうち, 南アフリカ共和国と ナミビアの固有種で全長約 $70 \mathrm{~cm}$, 体重 $2.5 \sim 3 \mathrm{~kg}$ のジャッカスペンギン (Spheniscus demersus, Jackass Penguin/African Penguin)（南アフリカ共和国で危急種に指定）は, 多くの船舶が航行す るケープタゥン周辺海域の流出油に頻繁に污染されてきた。この救護を目的に 1968 年に設立 された南アフリカ沿岸性鳥類保護财囘 (South African National Foundation for Conservation of Coastal Birds)（通称 SANCCOB）は 1969〜1974 年の 7 カ年だけでも計 5,550 羽のジャッカス ペンギンを救護し，そのうち 3,614 羽を放鳥している（Frost ら 1976）。1981〜1991 年には 4,215 羽が油污染して SANCCOB に収容され，ジャッカスペンギンの年平均収容数は，1980 年 代半ば時点での同種の推定総個体数 162,771 羽の 0.24\%にあたる (Adams 1994)。1970 年代前 半の 3 ヶ年に標識放鳥した油污染経験ジャッカスペンギン 1,440 羽のうち $1.8 \%$ の死体が回収 されている (Frost ら 1976)。この死体回収率は油污染経験ウミガラスの死体回収率 4.4\% (263 羽/5907 羽) の半分に満たない。

油に污染して救護されたジャッカスペンギンの放鳥後の生残についての肯定的報告は，既に 1980 年に Randall らにより次のように行われている。1979年 7 月油污染した 150 羽のジャッ カスペンギンが集団繁殖地のある南アフリカの St. Croix 島から SANCCOBに輸送され，油の 洗浄・リハビリ後, 回復した 100 羽が島から $600 \mathrm{~km}$ 西のケープタウン近くの洋上で放鳥され た。半年後の翌 1980 年 2 月までに, そのうちの $87 \%$ が約 $650 \mathrm{~km}$ 離れた St. Croix 島で目視さ れた。健康な様子で, 通常の換羽もしており，巣に戻り，番い行動をし，そのうち6 羽は産卵 していたと記している。

最新の肯定的な報告は Underhill ら (1997) が次のように行っている。1994 年 6 月, 南アフリ 力共和国南西部沖にある本種最大の繁殖島 Dassen 島近くで貨物船が沈没し，流出した燃料用 重油で多数のジャッカスペンギンが油污染し，SANCCOBに収容され放鳥された計 5,213 羽の 
うち，金属製翼標識を付けた 4,076 羽をその後の 3 年間, 生態調查基地のある同 Dassen 島と, 隔週を目安に渡島した Robben 島などで目視調査し, 記録を集積した。その結果, 死亡率が最も 高いと予想される放鳥直後の 1 ヶ月を生残した鳥は全標識鳥の $68 \%$ にあたる計 2,792 羽, 放 鳥後まる 1 年以上 2 年末満生残したのは全標識放鳥数の約半分で, 次いで放鳥後まる 2 年以上 少なくとも 3 年末満生残した鳥の総個体数は全標識放鳥数の $38 \%$ にあたる計 1,548 羽であっ た。放鳥後 1 年後から 2 年間の生残率は 84\%(2353/2792)（2353 羽は放鳥して 1 年間は生存が 不明だったが，その後の 2 年間に生存が確認された鳥の合計数）となり，放鳥後 3 年間に繁殖 島で目視された総計 2,792 羽のうち, 放鳥 2 年目あるいは 3 年目に死亡した可能性のある（再 目視されなかった）個体は，2 年合計で僅かに 439 羽 (16\%)に過ぎない。これを本種の繁殖域 の最南東部 St. Croix 島個体群の成鳥の年死亡率 $9 \%$ （La Cock ら 1987）と比較すると, 油污染 リハビリ経験鳥の放鳥 1 年後以降の死亡率は, 通常の個体群に遜色ない。その後の経過と生残 した油污染経験ペンギンがどの程度繁殖に参加したかについては一切触れられていない (Underhill らが近く発表する予定の査読制の英国鳥学誌 Ibis で, この点が明らかになることを期待 する)。

SANCCOB とは別個に救護活動を行った南アフリカ共和国のポートエリザベス大学の Kerleyらは, 1985 年に油污染し救護したジャッカスペンギン 84 羽のリハビリ中の生残状態 を, 収容時と放鳥時の体重とその間の体重の経日変化, 収容期間, 洗浄方法について検討して いる。その結果, 収容時に体重の軽い個体にリハビリ中の死亡率が高いため, 重い体重の個体 の選別リハビリの必要性と, 油の効果的な洗浄時期と方法について提言を行っている (Kerley \& Erasmus 1987)。だが，いずれの研究でもリハビリ中の生体情報と放鳥後の生残の相互関係に ついての解析は行われていないため, どのような要因がジャッカスペンギンの放鳥後の生残に 好影響を与えているのか, 直接の手がかりを得ることができない。

\section{2-2. 今後の課題}

このように, 南アフリカ共和国で精力的にリハビリが行われてきた油污染ジャッカスペンギ ンの救護放鳥後の高い生残が, 北半球で油污染被害数が最多で, ゆえに集中的に救護され放鳥 されてきたウミガラスなどから提出された複数の結果と相反する原因は, 1998 年夏, 国際鳥学 者会議の油污染海鳥のリハビリに関する円卓会議で大きく次の 2 点から議論されたが, 不明で あった (Wernham \& Williams 1998)。まず，1) 研究手法の違いが大差を生む可能性については, 標識回収データによる生残率の計算モデルを再検証することが必要だとされたが, 標識回収 デー夕に基づく間接調查法が大差を生んだ可能性は否定された。油污染鳥は放鳥時に必ず個体 識別のできる標識をすることと, 集団繁殖鳥で目視調查が行える条件が整う種では, 油污染標 識鳥の目視調査の実施が望ましいとしている。2) リハビリ方法の差が生残に大差を生んだ可 能性については, 検証するためのリハビリ中の個体の情報が不足するため, 詳細な分析が不可 能となっている。北半球でのリハビリ鳥の生残率を上げるために, リハビリ技術の向上は不可 久であり, そのために必要なカルテ（収容して放鳥までの鳥 1 羽づつの生体情報, 取り扱い, 処置方法など）の細目が議論され，そのリストが提出された。ついで, 油の摂取が免疫システ ムを低下させる可能性が共通の認識として提出され, 今後の研究の主要課題と位置づけてい る。救護鳥の血液などの採取による生体情報の収集の必要性も臨床獣医師から要望されている 
(Newman 1994)。

放鳥後の生残結果からみる限り, 他種に比ベてペンギンの油污染に対する高い耐性は, 羽毛 構造の違いと, 抱卵時, 換羽時に曝される長期の絶食への耐性とそれに伴う栄養生理・生態的 特徴之, 後肢筋の強さなどに伴う陸上生活への耐性が, 保護飼育時に有利に働く可能性がある 点が, 現時点で予想される。羽毛に油が付着すると低温環境では極めて高い熱消耗が発生する ことが知られており，特に微細な羽毛構造を持つ鳥種では致死原因にもなると考えられる (Jenssen 1994, 梶ヶ谷・岡 1999, 他)。むし, 救護りハビリ方法に大差が無く, さらに油の摄取 による免疫システムの低下の発現が，本論文で議論された種間あるいは体サイズ間（最小のク ビナガカイッブリ $0.6 \mathrm{~kg}$ 最大のカッショクペリカン $3.5 \mathrm{~kg}$, ジャッカスペンギン $2.5 \sim 3 \mathrm{~kg}$ ) で仅に大差がないとしたら, 先に述べたペンギン特有の硬く短い羽毛と厚い皮下脂肪層を形成 する体構造と栄養生理的特徵と, 換羽中は陸で過ごす行動習性などの総和が, 油污染リハビリ 後に放鳥されたペンギン類の熱消耗による衰弱を防ぎ，回復への耐性を生み出す要因になって いるのかむしれない。同じ潜水種のなかであジャッカスペンギンの生息海域が，否定的報告が 相次いだ欧米の油污染ウミガラスなどの主要生息海域の北緯 50〜60 度と比べて 15 度以上も緯 度が低い南緯 35 度海域であるため, 油の流出事故が多発する冬期でも 1 日の明期が比較的長 いため太陽放射熱を受け易く, ジャッカスペンギンが周年繁殖 (Williams 1995) することが示 唆するように, 南アフリカ西岸を北上するベンゲラ海流の餌資源量が季節的に大きく変動せ ず，冬期も索飳環境が整うことが，油污染経験鳥の放鳥後の生残に有利に働いているのかもし れない。

熱帯域のウ類では, 1991 年ペルシャ湾の湾岸戦争で油污染しリハビリ放鳥したウ類数羽が繁 殖した情報を, 現地からの私信としてWarheit ら (1997) が記している。放鳥後の生残にはそれ ぞれの種の生息環境亡生態的特性も大きく影響するため, 臨床的・獣医学的研究と生態学的研 究の両面のアプローチが欠かせないと考えられる。

\section{海鳥の救護効果の結果に基づく油污染対策の提言}

これまで少なくとも 3〜4万羽の油污染海鳥が救護され放鳥されてきたが, ペンギン（ジャッ カスペンギン）を除き，放鳥後の生残は今のところ極めて悪い。Warheit ら (1997) は, 絶滅危 惧種など特例的な場合以外では, 投入費用と得られる成果を総合的に考えて, 油污染鳥の救護 は一般的に保全に貢献していないとする。その上で, リハビリ技術の向上で将来, 放鳥後の生 残率が高まり, リハビリコストが相対的に莪減されることで, 海鳥の将来の保全戦略の選択肢 の一つになりえるかすしれないとみる。

有効な防御法が講じられない限り, 海洋への油の流出は今後む続くとみなければならない。 個々の生物種を保全する場合, 種, 地域個体群, 個体の, それぞれの位置づけが必要になる。 一度に多数が被害を受け, 迅速な対応が求められる洋上の油污染の場合では, とりわけ効果的 な保護あるいは保全へ向けての戦略的な対応が必要である。現状では, 総個体数が少ない種を 優先的に救護し，重点的にリ八ビリを試みることが，まず不可欠である。最新のレッドデー夕 ブックは海鳥の保全の優先順位を考える上で指針となる。さらに油污染した個体がどこの地域 個体群の出身であるかを知ることあ, 今後の保全の立案の上で必要な情報の一つになる。 
先にみたジャッカスペンギンは総個体数が 1980 年代半ばに約 16 万羽と推定されており (Adams 1994), この数は 1930 年頃までの主要繁殖島 1 島の推定個体数（Frost ら 1976）に相当 し, 1970 年代後半時の推定総個体数 20 万 5 千羽と比較しても，10 年弱で約 $20 \%$ 減少している (Adams 1994)。BirdLife International の最新のレッドデータリスト（Collar ら 1994）では準危 惧種 (Near-threatened species) に指定されている。生息個体数の減少の最大の要因は漁業によ る餌資源の枯渇にあることを複数の研究者が指摘しており（e.g., Frost ら 1976, Randall \& Randall 1986), 個体群全体での成鳥の年死亡率に, 油污染が直接起因する割合は $2.6 \%$ と推定され る一方 (Adams 1994), 繁殖地によっては死因の 40\% を占め, 総個体数そのものの少なさとあ いまって，油污染が地域個体群へ及ぼす影響は決して無視できない状況下にある（Randall ら 1980)。1981〜1991 年にはその前の 11 年間に比べて, SANCCOBへの油污染ペンギン収容数が 24\% 6減少している (Adams 1994)。これは, 南ア海域では, 1979 年以降, 西に航行し, さら に南アの港と交易しない油搭載タンカーは夏季には 25 海里（約 $46 \mathrm{~km}$ ) 以上沖合いを航行する ことを義務付け，また，油による海洋污染防止法 (Prevention and Combating of Pollution of Sea by Oil Act) の施行で, 沿岸 12 海里（約 $22 \mathrm{~km}$ ）以内では油すべてに関して, 50 海里 (約 $93 \mathrm{~km}$ ) 以内では $100 \mathrm{ppm}$ 以上の油を含む溶液や水の排出を禁じている。Adams (1994) は, こうした 沿岸域での油の流出阻止の立法化と施行, 違反した場合の罰則の強化と, 沿岸域の警視活動と いった污染防除の連携システムが, ペンギンの油污染数の減少に貢献したとみている。

日本での海洋污染は, 海上保安庁の発表によると 1998 年には 699 件が確認され, そのうち船 舶による重油などの油の流出が, 年間確認数の $56 \%$ にあたる 389 件を数えている。油污染した 鳥を救護しても保護効果が極めて低いと予想される今日, 最も要望されることは，1) 油污染防 止の徹底と，2) 油污染した時の迅速な回収と，生態系へ二次污染を伴わない方法による油の無 害化である。油污染の防止には，タンカーの二重底化と，あらゆる船舶の燃料タンクの構造強 化, 油污染を防止する港湾設備の充実 (廃油回収施設の設置之利用しやすい運用), 油污染防除 の法律の強化, 污染の監視, 罰則の強化, 海上従事者への海洋污染防止の普及活動なよ゙, 油污 染を防除するきめ細かいシステム作りが不可欠である。流出した油の化学処理剂 (界面活性剤) は油污染鳥にとって，特に低温環境では油そのあのよりも危険性を一層高めると考えられ (梶ヶ谷・岡 1999, 他), また界面活性剤は生態系の污染原因ともなるため, 積極的使用は控え るべきである。

英国では今世紀初頭以降から半世紀余りに及ぶ大型力モメ類の激増で，小型海鳥の地域的絶 滅あるいは滅少が引き起こされてきた（Lloydら 1991）。それを受けてウエールズのメイ島で 1972 年以来, 大型カモメの大規模な駆除が 3 年連続で行われ，以後約 10 年小規模な駆除を継 続している（Coulson 1991, Lloyd ら 1991）。その結果，大型カモメの繁殖数が最大規模だった 42,000 番いから 3,000〜4,000 番いに減少した時点で, 地域個体群が一度は絶滅していたアジサ シ (Sterna hirundo), キョクアジサシ (S. paradisaea), サンドイッチアジサシ (Thalasseus sandvicensis) などが再び入植し, 復活している。この例は, 海鳥の保全は, それぞれの海鳥種の生活 史の特性（繁殖年齢, 産卵数, 生残率, 繁殖地, 生息域の特徵など), 種間関係, 個体群規模な よ゙を視野に入れて行うことの重要性の一端を示している。油污染した海鳥の救護活動も, 日本 周辺の海域での海鳥の通年の生息状況, 個体群規模, 生活史の特性, 種間関係などを把握し, あらかじめ重点的に救護する種の策定と救護保全システムの総枠づくりを行いながら, 効果的 
に進めることが不可欠であることを示す。

謝辞

オランダ海鳥研究グループの研究誌 Sula の該当文献の入手に迅速な便宜をはかって下さり, 筆者が参加できなかった第 22 回国際鳥学者会議の油污染リハビリ海鳥ワークショップで論議 された結果をお知らせ下さった英国鳥学基金 (British Trust for Ornithology) の C. Wernham 博 士に感謝申しあげます。本研究は, 1997 年 1 月ナホトカ号重油流出事故を契機に (財) 日本鳥類 保護連盟を通じて環境庁から支援を受けた。環境庁の水谷知生氏，日本鳥類保護連盟の箕輪多 津男氏，油污染の文献の入手に尽力をいただいた山階鳥類研究所鶴見みや古氏，本稿の校閲を いただいた同黒田長久所長と東京大学樋口広芳教授, Abstract の英語をみていただいたカリ フォルニア大学デイビス校の John Fries 氏をはじめ, 関係諸氏，機関にお礼を申しあげます。

\section{摘要}

油の流出は, 特に 20 世紀後半に入り, 大陸棚・沿岸域に生息する海鳥にしばしば多大な被害 を及ぼしてきた。日本でも 1997 年 1 月に日本海でロシア船から多量の重油が流出し, 海鳥が油 污染の被害を受け，海岸で発見されたものだけであ 1,315 羽が死亡あるいは衰弱している。そ のうち約 90 羽が救護され洗浄, リハビリ後に, 放鳥された。油污染鳥の救護の歴史は幾つかの 国々で長く，これまで全体で，少なくとも3〜4万羽の油污染海鳥が救護され放鳥されている。 油を洗浄し放鳥された海鳥が生残し，それぞれの個体群の動態に関与できているかの検証が, 保全生物学的な観点からここ10 数年来, 要望されてきた。本稿は海外 (英国, オランダ, 北米, 南アフリカ共和国) で最近相次いで提出された油污染リハビリ海鳥の放鳥後の生残についての 研究結果に基づき，リハビリ放鳥された油污染経験海鳥の動向を考察し，現状と問題点を整理 した。

標識放鳥された海鳥の回収状況から推定された放鳥後の生残率と生残日数は, 亜高緯度海域 で救護後に標識放鳥された潜水性海鳥 4 種（ウミガラス, クビナガカイッブリ，ビロードキン クロ，アラナミキンクロ）ですべて著しく悪く，たとえば英国のウミガラスで放鳥初年の生残 率が $0.6 \%$, 北米のウミガラスの平均余命が 9.6 日と推定されている。電波発信機を装着し追跡 した中緯度海域の水面採食型のカッショクペリカンでは, 先の潜水性海鳥よりも生残期間が長 かったものの, 繁殖に参加できていない。これとは対照的に, 南アフリカ共和国で救護され, 標識放鳥された中緯度海域のジャッカスペンギンは, 放鳥初年度に約半数が生残し, 次年度の 年生残率は健常個体群に匹敵していた。このペンギンは国際レッドデータブックで準危惧種に 指定されており, 油污染個体のリハビリ放鳥は, この種の地域個体群, あるいは場合によって は種個体群そのものの減少を幾分緩和するのに成功してきたとみなせるだろう。油污染した海 鳥を救護して放鳥しても現状では保全効果がない北半球の浅海・沿岸性潜水型鳥類や表面採食 型鳥類で，有効なリハビリ技術が開発され，今後これらの鳥類の生残を高めることが可能とな れば, 積極的な保全要請の高い絶隇危惧種あるいは危急種などが油污染した場合に, 有効な救 護手段の一つになりえると考えられる。 


\section{引用文献}

Adams, N. J. 1994. Patterns and impacts of oiling of African penguins Spheniscus demersus: 1981-1991. Biol. Conser. 68: 35-41.

Anderson, D. W., Gress, F. \& Fry, D. M. 1996. Survival and dispersal of oiled Brown Pelicans after rehabilitation and release. Mar. Pollut. Bull. 32: 711-718.

Camphuysen, C. J., Duiven, P., Harris, M. P. \& Leopold, M. F. 1997. Recoveries of Guillemots ringed in the Netherlands: The survival of rehabilitated oiled seabirds. Sula 11: 157-174. (in Dutch with English abstract, summary and figure and table explanations)

Clark, R. B. 1978. Oiled seabird rescue and conservation. J. Fish. Res. 35: 675-678.

Collar, N. J., Crosby, M. J. \& Stattersfield, A. J. 1994. Bird to watch 2: The world list of threatened birds. Birdlife International, Cambridge.

Coulson, J. C. 1991. The population dynamics of culling Herring Gulls and Lesser Black-backed Gulls. pp. 479-497 in Bird population studies, Perrins et al. (eds.). Oxford Univ. Press, Oxford.

del Hoyo, J., Elliott, A. \& Sargatal, J. 1992. Handbook of the birds of the world, Vol. 1. Lynx Edicions, Barcelona.

Estes, J. A. 1998. Concerns about rehabilitation of oiled wildlife. Conserv. Biol. 12: 1156-1157.

Frost, P. G. H., Siegfried, W. R. \& Cooper, J. 1976. Conservation of Jackass Penguins (Spheniscus demersus (L.)). Biol. Conserv.: 80-99.

Gaston, A. J. \& Jones, I. L. 1998. The auks. Oxford Univ. Press, Oxford.

Harris, M. P. \& Wanless, S. 1997. Successful rehabilitation of oiled guillemots Uria aalge. Sula 11: 151-153.

Jenssen, B. M. 1994. Effects of oil pollution, chemically treated oil, and cleaning on the thermal balance of birds. Environ. Pollut. 86: 207-215.

梶ヶ谷 博・岡 奈理子. 1999. 油污染が鳥類の体に及ぼす影響. 山階鳥研報 31: 16-38.

Kerley, G. I. H. \& Erasmus, T. 1987. Cleaning and rehabilitation of oiled jackass penguins. S. Afr. J. Wildl. Res. 17: 64-70.

La Cock, G. D., Duffy, D. C. \& Cooper, J. 1987. Population dynamics of the African penguins Spheniscus demersus at Marcus Island in the Benguela upwelling ecosystem. Biol. Conserv. 40: 117-126.

Lloyd, C., Tasker, M. L. \& Partridge, K. 1991. The status of seabirds in Britain and Ireland. T \& A D Poyser, London.

Maki, A. W. 1990. The Exxon Valdez wildlife rescue and rehabilitation program. Trans. N. Amer. Wildlife. Conf. 55: 193-201.

マゼット，J. 1998. カリフォルニア州における油污染野生生物救護ネットワーク・官民共同で行われる対策 活動について. 野生動物救護獣医師協会, (財)世界自然保護基金日本委員会, 日本ウミスズメ研究会, 日本財団(編), ナホトカ号油污染鳥類の保護保全活動から何を学ぶか? 環境保全における危機管理の 将来像, 96-105 頁. 日本財団, 東京.

Mead, C. 1997. Poor prospects for oiled birds. Nature 390: 449-450.

Nelson-Smith, A. 1970. The Problem of Oil Pollution of the Sea. Pp. 215-306 in Advances in Marine Biology, F. S. Russell \& M. Yonge (eds.) Academic Press, London \& New York.

Nelson-Smith, A. 1972. Oil Pollution and Marine Ecology. Paul Elek (Science Books) Ltd., London.

Nettleship, D. N. \& Evans, P. G. H. 1985. Distribution and status of the Atlantic Alcidae. pp. 53-154 in The Atlantic Alcidae, D. N. Nettleship \& T. R. Birkhead (eds.). Academic Press, London.

Newman, S. 1994. Oil spill rehabilitation: beware of research. Pacific Seabirds 21: 2.

Randall, R. M. \& Randall, B. M. 1986. The diet of Jackass Penguins, Spheniscus demersus, in Algoa Bay, South Africa, and its bearing on population declines elsewhere. Biol. Conserv. 37: 119-134.

Randall, R. M., Randall, B. M. \& Bevan, J. 1980. Oil pollution and penguins: Is cleaning justified? Mar. Pollut. Bull. 11: 234-237.

Sharp, B. E. 1996. Post-release survival of oiled, cleaned seabirds in North America. Ibis 138: 222-228.

Underhill, L. G., Whittington, P. A., Crawford, R. J. M. \& Williams, A. J. 1997. Results of monitoring oiled African Penguins Spheniscus demersus for three years after the Apollo Sea incident of June 1994. Sula 11: 187-192. 
Vauk, G. 1984. Oil pollution dangers on the German coast. Mar. Pollut. Bull. 15: 89-93.

Warheit, K. I., Harrison, C. S. \& Divoky, G. J. 1997. Exxon Valdez Oil Spill Seabird Restoration Workshop. Exxon Valdez Oil Spill Restoration Project Final Report, Project 95038. Techn. Publ. No. 1. Pacific Seabird Group, Seattle.

Wernham, C. V., Peach, W. J. \& Browne, S. J. 1997. Survival rates of rehabilitated Guillemots. BTO Research Report No. 186. BTO, Thetford.

Wernham, C. V. \& Williams, T. J. 1998. RT03: Rehabilitation of oiled seabirds. Extended abstract for the CD-rom proceedings of IOC.

Williams, T. D. 1995. African or Jackass Penguin. pp. 238-245 in The penguins. Oxford Univ. Press, Oxford. 